Working Paper No. 583, 2002

Commercialization of Swedish Patents -

A Pilot Study in the Medical and Hygiene Sector

by Roger Svensson

IUI, The Research Institute of Industrial Economics

P.O. Box 5501

SE-114 85 Stockholm

Sweden 


\title{
Commercialization of Swedish Patents - A Pilot Study in the Medical and Hygiene Sector
}

\author{
Roger Svensson \\ The Research Institute of Industrial Economics (IUI) \\ Box 5501, S-114 85 Stockholm, Sweden \\ rogers@iui.se
}

October 2002

Key words: Patents, R\&D, commercialization, financing, entrepreneurship.

JEL classification: M13, O32.

\begin{abstract}
In this paper, I analyze the commercialization of patents in the Swedish medicine \& hygiene sector. A unique database makes it possible to use a new method, where I follow the commercialization process of individual patents. A surprisingly low share (10\%) of the inventions was discovered at universities or in firms close to universities, although $1 / 3$ of total R\&D is undertaken at universities in Sweden. The commercialization rate is higher among small firms and entrepreneurs compared to medium-sized and large firms, but the success rate is lower for the former groups. With respect to mode of commercialization, $90 \%$ of the patents are commercialized in existing firms and only $10 \%$ in new startups. Few patents are sold or licensed abroad, and even then, manufacturing of the invention often takes place in Sweden. It seems like there is a lack of external venture capital to a higher degree in the commercialization phase than in the R\&D phase. Entrepreneurs and small firms often claim that financing and difficulties to find a firm willing to manufacture the invention are the largest problems during the commercialization, or the main reasons why the patent was not commercialized. The reasons why larger firms do not commercialize their patents are that they often give priority to other inventions, or utilize the patent as a "shadow patent" in order to prevent competitors to use the invention.
\end{abstract}

* The author would like to thank Magnus Henrekson and Ulf Jakobsson, IUI, as well as Pontus Braunerhjelm, SNS, and Dan Johansson, Ratio Institute, for constructive comments. Financial support from Vinnova is gratefully acknowledged. 


\section{Introduction}

During recent years, inventions created through research and development (R\&D) have become more important for firms' competitiveness in strategic sectors like telecom, IT, medicine and biotechnology. A basic issue is how to facilitate the commercialization of the inventions created in the corporations and at the universities.

Sweden is one of the countries in the world that spends most resources on R\&D compared to GDP - both totally and in the universities (SOU 1996:70). Sweden is also top-ranked with respect to publications in international academic journals in relation to GDP (National Science Board, 1997), and granted patents per capita (EU, 2001). On the other hand, there are not so many small technology-based fast-growing firms in Sweden, which use the knowledge and innovations resulting from R\&D effort. Apparently, the commercialisation of the patents and the intellectual capital does not work so efficiently in Sweden (Utterback and Reitberger, 1982; Rickne and Jacobsson, 1996, 1999; Goldfarb and Henrekson, 2001). Other studies show that newly started technology-intensive firms originating from universities do not grow faster than other start-ups in Sweden (Olofsson and Wahlbin, 1993; Lindholm-Dahlstrand, 1997a, 1997b). A comparison can be made with the US, which also spend large resources on R\&D. In the US, however, there are many small firms, which - by basing their competitiveness on innovations - have grown large in sectors like medicine, microbiology, IT and electronics.

This paper is related to the phenomenon that Sweden has a leading position with respect to $R \& D$, patents and publications, but not so many small fast-growing technology-based firms. The main purpose is to analyze the commercialization process of Swedish patents. Several questions related to the commercialization process are going to be analyzed: the mode of commercialization, financing of $R \& D$ and commercialization, whether the inventors are owners of the patent and have an active role during the commercialization, if there is no commercialization - why not?

In order to get at better general picture of the patents, I have chosen a method where I follow how and if individual patents are commercialized. As nobody has used this method before, it is risky. Therefore, a pilot study is undertaken in a specific sector in Sweden - the medical and hygiene sector. Earlier Swedish studies of commercialization of inventions have only analyzed start-up firms, although a majority of the patents and inventions probably are commercialized in existing firms. In the US, for example, $90 \%$ of the patents are commercialized in already existing firms (AUTM, 1998). 
Furthermore, the interesting question is not whether inventions and patents lead to new firms, but whether they translate into a higher standard of living.

The paper is organized as follows. Section 2 describes the database and sample selection. Some basic data about the inventions and patents is shown in section 3. In section 4 , the choice to commercialize the patents is analyzed. In section 5 , the mode and financing of the commercialization are investigated. Miscellaneous aspects of the commercialization are discussed in section 6 , and the final section concludes.

\section{Database and sample selection}

When following the commercialization of patents, it would be desirable to have a database with information about individual patents, i.e., a database where the patent is the unit of observation. To the best of my knowledge, no such database has ever been collected before. Therefore, I decided to make a pilot study about the commercialization of patents in a specific sector in Sweden based on such a database. I chose granted patents in the medical \& hygiene sector in 1994. This sector is known to be R\&Dintensive and is large enough to generate a large sample. I also chose the year 1994, because I expected that there are some years between the patent is granted and it is possible to see any effects of the commercialization.

In 1994, 123 patents were granted in the medical \& hygiene sector in Sweden. Information about inventors, applying firms and their addresses for each patent was bought from the Swedish Patent and Registration Office (PRV). Thereafter, a questionnaire was sent out to the inventors of the patents. Each patent has always at least one inventor and sometimes also an applying firm. The inventors or the applying firm can be the owner of the patent, but the inventors can also be owners of the patent indirectly, via the applying firm. Sometimes the inventors are only employed in the applying firm, which owns the patent. If the patent had more than one inventor, then the questionnaire was sent to only one inventor. In the questionnaire, which is fully described in the Appendix, we asked the inventors about the work place where the invention was created and the financing of the invention, whether the invention had been commercialized and in such a case how, how the commercialization was financed, about the inventors' incomes and profits from the patent, and if there were any problems with the commercialization - alternatively, why the invention / patent never was commercialized. We also made telephone interviews with the inventors after they had filled in the questionnaire in order to get complementary information. 
As many as 77 of the inventors filled in and returned the questionnaire, i.e., the response rate was $63 \%$ (77 of 123). This response rate is satisfactorily high, if one takes into account that such a database has never been collected before and that the inventors or the applying firms usually consider information about inventions and patents secret.

The reasons why 46 inventors did not fill in, and return, the questionnaire can be seen in Table 1. In this table, the inventors are sorted according to in which kind of firm they were employed when they made the invention. One main reason was that, in the case of large companies, the applying firm prohibited the inventors to fill in the questionnaire (10 lost observations). Large firms often consider information about patents as a company secret. Another problem was to get into contact with inventors, especially when they were alone and were not employed in any firm (17 lost observations). This is due to the fact that many of the addresses of the inventors, supplied by PRV, were outdated.

\section{[TABLE 1]}

Table 2 describes how the response rate varies across different kind of firms where the inventors were active. The response rate is the lowest in the group where the inventors are alone (entrepreneurs) and when they own, or are employed in, a small firm. Although one group (medium-sized firms) has full response rate, this group is small and has only eight observations. We still believe that the sample is representative enough to make an appropriate analysis of the commercialization process. It is interesting to note that large firms account for only about $25 \%$ of the patents, both in the population (among the 123 observations) and in the sample (among the 77 observations).

\section{[TABLE 2]}

When collecting the questionnaires, we sent out a reminder to those inventors who had not returned the questionnaire after three weeks. We contacted those inventors, who neither had replied after the reminder, by telephone. Sometimes we had to persuade them to fill in the questionnaire. When calling inventors who worked alone and asked them why they had not filled in, and returned, the questionnaire, many of them answered that there was no idea to participate in the investigation because they had 
failed to make their invention profitable. By calling these inventors, we succeeded in including also such observations in the sample and to avoid a biased sample.

All in all, the questions in the questionnaire have a good response rate, given that the inventors have filled in and returned the questionnaire. The exception is the question about the inventor's incomes or profits of the commercialization. Here, it was difficult for the inventors to estimate the volume of incomes, profits and fees.

\section{Inventions}

In Table 3, the 77 patents in the sample are distributed on the type of firm or place where the inventors were active when the invention was discovered. In this paper, we will frequently use this division of the patents on firm sizes, because this is perhaps the most important aspect when considering the conditions of commercialization. There is a huge difference in resources to commercialize patents between large firms, small firms and inventors who work alone, for example, with respect to financing, marketing and knowledge about rules and regulations.

Large and medium-sized firms account for 20 and 8 patents, respectively. In these groups, the inventors are employed in the firm and not owners of the patent. In small firms and close companies, the inventors are, on the other hand, mostly owners of the patents directly or indirectly. These groups have 8 and 11 patents, respectively. The largest group is when the inventors are alone. ${ }^{1}$ Here, 30 patents can be found, of which 6 were in connection with a university. Remarkable is that only 8 patents (about 10\%) were granted to inventors working at, or in a firm in connection with, a university. ${ }^{2}$ I had expected a larger share, especially if one considers that almost $1 / 3$ of total R\&D in Sweden is undertaken at universities (SOU 1996:70). ${ }^{3}$

However, the R\&D undertaken in the universities does not need to result in patents at the universities. Jaffe (1989) has shown in an American study on state-level that university $R \& D$ may spillover in more industry $R \& D$ as well as in more patents in corporations in the same region. This result was especially found in the medicine and drugs industry. The mechanisms behind these spillovers would be informal conversa-

\footnotetext{
${ }^{1}$ Either as private individuals or in close companies where only the inventors are employed.

${ }^{2}$ One of the purposes when we planned this study was to analyse the commercialisation of inventions found in the university sector. The surprisingly few observations in this group made it, however, difficult to undertake an appropriate analysis. Therefore, we partly changed the contents of this study.

${ }^{3}$ This share is likely to be even higher in the medicine sector, based on the number of post-graduated researchers employed in corporations and at universities in the medicine sector in Sweden (SOU 1996:70).
} 
tions between universities and corporations, and that the universities supply a pool of highly educated researchers for the local corporations.

\section{[TABLE 3]}

In Table 3, it is also shown how the R\&D that created the invention was financed. In large, medium-sized and small firms, the applying firm itself almost always finances the $R \& D$ behind the patent. In close companies, the inventors finance the R\&D when they are sole owners. It is only in the last group (inventors alone) where there is some form of external financing to a larger degree - financing from the government, private venture capital firms or universities. In total, 14 patents had at least co-financing from external financing sources.

All 77 patents in the sample were granted in 1994, but the application year varied in the following way: 7 patent applications were filed in 1989, 9 in 1990, 9 in 1991, 25 in 1992 and 27 in 1993. The average application year was 1992 and the average did not differ much across the five firm size groups.

In Table 4, the patents are distributed according to firm size and number of inventors. For most patents (47 of 77 patents), there is only one inventor, but on average there are almost two inventors per patent (126 inventors divided by 77 patents). Only 12 out of 126 inventors, or 10 percent, were women. Furthermore, the women were mostly not employed in any firm.

\section{[TABLE 4]}

\section{Commercialization}

By commercialization of patents is meant that the owners of the patent have taken measures with the purpose to generate incomes from the patent. For the whole sample, 34 out of 77 patents granted in 1994, or $44 \%$, had started commercialization before 2002. This is described in Table 5. In large and medium-sized firms, the commercialization rate is only $25 \%$, whereas the rate is significantly higher in smaller firms and when inventors are alone, and especially in close companies.

An overall impression from numerous interviews with persons responsible for patents in large companies is that large companies to a high degree apply for patents in a defensive way - in order to prevent competitors from using the invention. Inventors 
working in small firms or alone, on the other hand, say that the patent is more an opportunity to create a new product and open up new markets. The latter inventors are often optimistic about their inventions and often expect a high commercial potential. Sometimes they are too optimistic, which may explain the higher commercialization rate.

There is also a significant difference in the rate of commercialization depending on whether the inventors were owners of the patent or not. If the inventors were owners, then $55 \%$ of the patents were commercialized compared to $27 \%$ if they were not owners. Also this difference may depend on the fact that the inventors are more optimistic about their own inventions.

\section{[TABLE 5]}

The patents and the commercialization rate are also described across sectors in Table 6 below. Medical facilities and hygiene articles are the largest groups, but the commercialization rate differs a lot across the groups. The rate is higher than average for the sectors drugs and substances, dentist tools and medical facilities. We will not undertake a deeper analysis of these differences, because we have chosen the firm size as the main basis for the analysis.

\section{[TABLE 6]}

The reasons why patents had not been commercialized before 2002 are reported in Table 7. Here, the inventors could mention one or two different reasons. Difficulties to find financing or to find firms willing to manufacture the product as well as better competing products within the firm or by competitors dominate. Some patents are simply "shadow patents", meaning that the owner apply for patents in order to deter competitors from utilizing the invention, and some patents are not ready for the market yet. It is obvious that the reasons differ depending on in which kind of firm the inventors were active. Large and medium-sized firms often have other inventions, which they prioritize, and have shadow patents. On the other hand, sole inventors have difficulties to find financing and firms that are willing to manufacture the product. Some inventors in small firms, close companies and who work alone have mentioned other problems with commercialization, which in my view are more related to starting a 
small private firm or run business in general, for example, high taxes, bureaucracy and rigid rules for employment, etc. (see literature, e.g., Henrekson and Johansson, 1999). Since these problems are not specific for commercialization of patents, I do not show or analyze them here.

\section{[TABLE 7]}

Table 8 shows when commercialization started. On average, commercialization started in 1993, i.e., one year before the patents were granted. This is surprisingly fast. Although the average starting year varies across firm size, there is no obvious pattern. The distribution of starting years is shown in Figure 1. For 28 out of 34 patents, commercialization started between 1991 and 1995. As the application year was 1992 on average, this means that many owners began to commercialize their inventions already when they applied for the patent. Of the 43 patents that have not been commercialized yet, 29 are "dead" and 14 are "alive", which means that they can still be commercialized according to interviews with the inventors. My conclusion is, however, that most patents in the sample already have been commercialized if one expects some kind of normal distribution of the starting year of commercialization.

[TABLE 8]

[FIGURE 1]

\section{Mode and financing of the commercialization}

In Table 9, the mode of commercialization is described. Most of the patents (22 of them) were commercialized in existing or applying firms, where the inventors either were employed or owners. Only four patents were commercialized in a new firm started up with the purpose to commercialize the specific patent. This is about $10 \%$ of the commercialized patents and is in line with American studies, which have shown that $90 \%$ of the patents are commercialized in existing firms (AUTM, 1998). In the Swedish debate, it is often claimed that patents are sold to foreign firms and commercialized abroad. ${ }^{4}$ However, in this small sample, only three of the commercialized patents were

\footnotetext{
${ }^{4}$ The fact that a patent is sold to a Swedish or foreign firm, may imply that the owners sold the whole firm, including the patent.
} 
sold or licensed to foreign firms. Furthermore, one of the patents, which first was commercialized in an existing (applying) firm, was later sold to a foreign firm. The fact that a patent is sold or licensed to a foreign firm does not necessarily mean that the production of the invention takes place abroad. Of the four patents sold or licensed to foreign firms, only two were manufactured abroad (one in Holland and one in the U.S.), however, not shown in the table. Furthermore, one of the large Swedish firms manufactured one invention both in Sweden and in Holland. Thus, totally 3 out of 34 inventions were manufactured abroad.

\section{[TABLE 9]}

Financing of the commercialization can be found in Table 10 below. The right side, where the inventors are owners of the patents, is the interesting part of the table. ${ }^{5}$ Of these 26 patents, six were sold or licensed to other existing (Swedish or foreign) firms. In interviews, most of the inventors of these patents told me that selling or licensing the patent was the only way to finance the commercialization, or to find a firm willing to manufacture the product. For a vast majority of the patents, the owners must finance the commercialization themselves, either through loans, investment of own capital or reinvestment of profits from their existing firms. What is interesting, and surprising, to note here is the lack of government and private venture capital. Only for two patents (see notes ${ }^{\mathrm{a}}$ and ${ }^{\mathrm{c}}$ in the table), government or private venture capital firms were willing to invest capital for the commercialization. This can be compared with the financing of R\&D behind the invention in Table 3 . Then, government or private venture firms (partly) financed the R\&D for 11 out of 77 inventions. The statistics is in line with our telephone interviews, where many inventors claim that it is easier to get external financing when the invention is detected than when the invention is going to be commercialized. Also other Swedish studies have claimed that there is a lack of venture capital for small firms in Sweden (Braunerhjelm, 1999; Braunerhjelm et al., 2001), especially in comparisons with the U.S. (Braunerhjelm et al., 2000).

[Table 10]

\footnotetext{
${ }^{5}$ It is easier for an established firm to finance the commercialisation.
} 
Whether the inventors were active or not during the commercialization phase is shown in Table 11. Almost all inventors were active during this phase, even if they were not owners of the firm or the patent. Also when the patent was sold or licensed (6 patents), the inventors were in some sense active, for example, through consulting services or employment.

\section{[TABLE 11]}

In Table 12, we show the juridical type of firm, in which commercialization was undertaken when the inventors were owner of the firms. In small firms (not shown in the table) and close companies, the juridical type is always a limited company. When the inventors are alone, there is a larger variation in the type of firm. Often the firm is a trading company or a private firm. One can imagine that the inventors, who work alone, often have a permanent work somewhere else and the invention is often some kind of extra work or hobby. This picture is also confirmed in telephone interviews with the inventors.

[TABLE 12]

\section{Incomes and performance}

In this section, I analyze incomes for the inventors and performance of the commercialization. As already mentioned in Section 2, the largest difficulties with the collection of information were to get good answers for the question related to the inventors' incomes from the patent. When the inventors are not owners of the patent, it was no idea to ask about the firm's incomes and profits, because they simply do not know. Therefore, I only asked about the inventors' incomes.

The inventors had often problems to estimate the incomes and profits. Sometimes the invention is a part of a larger system, meaning that it is difficult to know the incomes, even if the inventors also are the owners. We also asked about how many years of employment the patent had generated in Sweden after the commercialization had started - both inventors who were and were not owners. This question was easier to answer, although there could be problems when the invention is a part in a larger system. Anyway, we have tried to make a rough estimation of whether the performance of the commercialization was "Very good", "Good", "OK" or "Bad". It is very easy to 
conclude which patents have given nothing to the owners, or when the patent has been a loss. These patents are regarded to have a "Bad" performance. The other three groups are more difficult to categorize. For these three groups we have taken into account incomes, profits and takeover fees for the owners, as well as number of working years generated by the patent. It should also be noted that those patents that have not been commercialized almost always are a loss for the inventors, due to fees to PRV and patent bureaus, as well as time and resources spent to create the invention. An exception is when a large firm uses the patent as a shadow patent and then can deter competitors from entering the market.

In Table 13, the performance of the commercialization is shown. The success rate is good in large, medium and small firms. For the group of close companies, the success rate is acceptable. However, for inventors working alone more than $50 \%$ of the patents is a loss for the inventors. There is an obvious trend in the table: the smaller the firm, the lower the success rate. Of the four patents commercialized in new firms, one had a very good, one had a good and two had a bad performance. If we look at the total sample of patents, also those patents, which were not commercialized, then 10 of 77 patents, or $13 \%$, were very successful, and 18 of 77 patents, or $23 \%$, had at least a good performance.

\section{[TABLE 13]}

Employment for the inventors during the commercialization and the number of working years generated in Sweden by the patent are shown in Table 14. In four groups, the inventors have got employment during the commercialization. For inventors, who work alone, the patent had generated paid employment for 3 out of 13 observations. However, if we look in the right part of the table, the patent can generate employment for other persons in Sweden, for example, if the patent is sold or licensed. As many as eight patents have generated more than 20 employment years in Sweden. Patents generating many jobs can also be found in the last group (inventors alone), but the probability that the patent generate many jobs increases with firm size. The worse performance of smaller firms and inventors who work alone can of course depend on that these inventors are overoptimistic about their inventions or that they have had problems to find financing and firms willing to manufacture the product (see Table 15 below). The 34 commercialized patents generated 16,1 working years on average up to the year 
2002. This high average depends on that three patents have generated at least 50 working years each.

\section{[TABLE 14]}

In Table 15, it is shown which kind of problems that occurred during the commercialization. As expected, smaller firms and inventors who worked alone had most difficulties. Financing seems to be the largest problem. This fact can be compared to Table 7, where the reasons why patents had not been commercialized were depicted. It seems also like many small inventors have been over-optimistic and have not been able to evaluate the potential of the product or whether the future client will accept the new product.

[TABLE 15]

\section{Concluding remarks}

In this study, I have analyzed the commercialization of patents in Sweden. A unique database has made it possible for me to use a new method, where I follow the comercialization process of individual patents. Since nobody has used this method before and information about patents often are kept secret by firms, the project was risky. Therefore, we made a pilot study for patents granted in 1994 in the medicine \& hygiene sector. However, the collection of information was satisfactorily successful. The response rate was $63 \%$. This response rate can be improved considerably: 1) If one chooses patents granted in a later year, then it will be more easy to get into contact with the inventors. Most patents are anyway commercialized around the year when they were granted; and 2) Large firms are excluded in the sample, because these firms are reluctant to give information about patents. Furthermore, patents in large firms seldom lead to new start-up firms (at least in this survey), and large firms often apply for patents in order to deter competitors from using the invention ("shadow patents").

The conclusions in this study are of course limited to a specific sector, but they are nevertheless interesting. A surprisingly low share $(10 \%)$ of the inventions were discovered at universities or in firms close to universities, although $1 / 3$ of total R\&D are undertaken at universities in Sweden. The owners had started to commercialize $44 \%$ of the patents in the sample up to 2002. The commercialization rate is higher among small 
firms and entrepreneurs (inventors who work alone) compared to medium-sized and large firms. This difference may depend on that small firms and inventors are more optimistic about their own inventions.

Only $10 \%$ of the patents were commercialized in new start-ups, and $90 \%$ in existing firms. This is in line with American studies. Around $10 \%$ of the commercialized patents are sold or licensed to foreign firms, and even then, manufacturing of the invention often takes place in Sweden. Small firms and inventors must almost always finance the commercialization themselves. It seems like there is a lack of external venture capital to a higher degree in the commercialization phase than in the R\&D phase. Entrepreneurs and small firms often claim that financing and difficulties to find a firm willing to manufacture the invention are the largest problems during the commercialization, or the main reasons why the patent was not commercialized. The reasons why larger firm do not commercialize patents are that these firms have a basket of inventions and often give priority to some of the other inventions. They often utilize the patent as a "shadow patent" in order to prevent competitors to use the invention.

The most difficult question to get information about was the inventors' incomes and profits of the commercialization. It is not easy for the inventors to give appropriate information about incomes and profits. These measurements must be improved in a future study. However, a rough measure of performance showed that the success rate for commercialized patents is lower for small firms and individuals compared to larger firms. Another measure of performance, the number of employment years generated in Sweden by the patent, had a better response rate. The commercialized patents generated 16 employment years on average. However, there was a large variation among the patents, where a few patents owned by large and medium-sized firms generated more than 50 employment years each. Also in this case, patents with few employment years could be found among small firms and inventors who work alone.

One of the purposes when I planned this project was to compare the Swedish commercialization process with how patents at American universities are commercialized. However, in our study we did not find enough with Swedish patents granted to individuals working at universities, or in firms close to universities to undertake such an analysis. In a future study with more observations this kind of analysis will be possible. 


\section{References}

Association of University Technology Managers, 1998, AUTM Licensing Survey, Association of Technology Managers, Norwalk CT.

Braunerhjelm, P., 1999, 'Venture capital, mångfald och tillväxt', (Venture Capital, Variety and Growth), Ekonomisk Debatt, 27, Nr 4, pp. 213-22.

Braunerhjelm, P., Carlsson, B., Johansson, D., and Karaomerliouglu, D., 2000, 'The New and the Old: The Evolution of Biomedical and Polymer Clusters', Journal of Evolutionary Economics, 10, pp. 471-488.

Braunerhjelm, P., Cetindamar, D. and Johansson, D., 2001, 'The Support Structure of the Biomedical Clusters: Research, Intermediary, and Financial organizations', in (ed.), Technological systems in the bio industries. An international study, Kluwer Academic Publishers, Boston, Dordretch and London.

EU, 1991, Towards a European Research Area. Key Figures 2001, Office for Official Publications of the European Communities, Luxemburg.

Goldfarb, B. and Henrekson, M., 2001, 'Bottom-Up vs. Top-Down Policies towards the Commercialization of University Intellectual Property', SSE/EFI Working Paper No. 463, Stockholm School of Economics, Stockholm.

Henrekson, M. and Johansson, D., 1999, 'Sysselsättnings- och företagsstrukturen: Endast Sverige snapsglas har, eller?', Ekonomisk Debatt, Vol. 27, pp. 139-49.

Jaffe, A., 1989, 'Real Effects of Academic Research', American Economic Review, Vol. 79, pp. 957-70.

Lindholm Dahlstrand, Å., 1997a, 'Growth and Inventiveness in Technology-Based Spin-Off Firms', Research Policy, Vol. 26, pp 331-44.

Lindholm Dahlstrand, Å., 1997b, 'Entrepreneurial Spin-Off Enterprises in Gothenburg, Sweden', European Planning Studies, Vol. 5, pp. 659-73. 
National Science Board, 1997, Science and Engineering Indicators, USGPO, Washington DC.

Olofsson, C. and Wahlbin, C., 1993, Teknikbaserade företag från högskolan, Institute for Management of Innovation and Technology (IMIT), Stockholm.

Rickne, A. and Jacobsson, S., 1996, 'New Technology-Based Firms - An Exploratory Study of Technology Exploitation and Industrial Renewal', International Journal of Technology Management, Vol. 11, pp. 238-57.

Rickne, A., and Jacobsson, S., 1999, 'New Technology-Based Firms in Sweden. A Study of Their Impact on Industrial Renewal', Economics of Innovation and New Technology, Vol. 8., pp. 197-223.

SOU 1996:70, Samverkan mellan högskolan och näringslivet, Huvudbetänkande av NYFOR, Fritzes, Stockholm.

Utterback, J.M. and Reitberger, G., 1982, Technology and Industrial Innovation in Sweden: A Study of New-Technology Based Firms, Center for Policy Alternatives, MIT and STU, Stockholm. 
Table 1. Reasons why inventors did not fill in and return questionnaire, by firm type where inventors were active, number of patents.

\begin{tabular}{|c|c|c|c|c|}
\hline \multirow[b]{2}{*}{$\begin{array}{l}\text { Type of firm where } \\
\text { inventors were active }\end{array}$} & \multicolumn{4}{|c|}{ Reason why the questionnaire was not filled in } \\
\hline & $\begin{array}{l}\text { Applying firm or } \\
\text { inventor(s) refused }\end{array}$ & $\begin{array}{c}\text { No contact } \\
\text { with inventor(s) }\end{array}$ & $\begin{array}{l}\text { Inventor(s) } \\
\text { sick or dead }\end{array}$ & Total \\
\hline Large firms ( $>1000$ employees) & 10 & 1 & 1 & 12 \\
\hline Medium firms (101-1000 employees) & 0 & 0 & 0 & $\mathbf{0}$ \\
\hline Small firms (11-100 employees) & 3 & 2 & 1 & 6 \\
\hline Close companies (2-10 employees) & 0 & 6 & 0 & 6 \\
\hline Inventors alone (1-4 inventors) & 1 & 17 & 4 & 22 \\
\hline Total & 14 & 26 & 6 & 46 \\
\hline
\end{tabular}

Table 2. Response rate across firm type, number of patents and percent.

\begin{tabular}{|c|c|c|c|c|}
\hline \multirow{2}{*}{$\begin{array}{l}\text { Type of firm where } \\
\text { inventors were active }\end{array}$} & \multicolumn{2}{|c|}{ Filled in questionnaire } & \multirow{2}{*}{$\begin{array}{l}\text { Total No. of } \\
\text { observations } \\
\text { in population }\end{array}$} & \multirow{2}{*}{ Response rate } \\
\hline & Yes & No & & \\
\hline Large firms (>1000 employees) & 20 & 12 & 32 & $62 \%$ \\
\hline Medium firms (101-1000 employees) & 8 & 0 & 8 & $100 \%$ \\
\hline Small firms (11-100 employees) & 8 & 6 & 14 & $57 \%$ \\
\hline Close companies (2-10 employees) & 11 & 6 & 17 & $65 \%$ \\
\hline Inventors alone (1-4 inventors) & 30 & 22 & 52 & $58 \%$ \\
\hline Total & 77 & 46 & 123 & $63 \%$ \\
\hline
\end{tabular}

Note: If the inventors are the only employees in a firm, then the inventors belong to the group "Inventors alone". Whether the inventors belong to the group "Inventors alone" or "Close companies" is sometimes somewhat uncertain, especially when we did not get into contact with the inventors. 
Table 3. Financing of inventions across firm type and inventor ownership, number and percent.

\begin{tabular}{|c|c|c|c|c|c|c|c|c|c|c|}
\hline \multirow[b]{2}{*}{$\begin{array}{l}\text { Type of firm } \\
\text { where inventors } \\
\text { are active }\end{array}$} & \multirow[b]{2}{*}{$\begin{array}{l}\text { Inventor } \\
\text { ownership }\end{array}$} & \multirow[b]{2}{*}{$\begin{array}{l}\text { No. of } \\
\text { patents }\end{array}$} & \multicolumn{8}{|c|}{ Financing of invention (number of observations) } \\
\hline & & & $\begin{array}{l}\text { Firm } \\
100 \%\end{array}$ & $\begin{array}{c}\text { Inventors } \\
100 \%\end{array}$ & $\begin{array}{c}\text { Government } \\
100 \%\end{array}$ & $\begin{array}{c}\text { Firm } 50 \% \\
\text { Inventors } 50 \%\end{array}$ & $\begin{array}{c}\text { Government } 50 \% \\
\text { Venture } 50 \%\end{array}$ & $\begin{array}{c}\text { Inventors 50\% } \\
\text { University } 50 \%\end{array}$ & $\begin{array}{c}\text { Inventors } \geq 50 \% \\
\text { Government } \leq 50 \%\end{array}$ & $\begin{array}{l}\text { Inventors } \geq 50 \% \\
\text { Venture } \leq 50 \%\end{array}$ \\
\hline Large firms & $0 \%$ & 20 & 19 & & 1 & & & & & \\
\hline Medium firms & $0 \%$ & 8 & 7 & & & & 1 & & & \\
\hline \multirow{3}{*}{ Small firms } & $0 \%$ & 1 & 1 & & & & & & & \\
\hline & Partly & 3 & 3 & & & & & & & \\
\hline & $100 \%$ & 4 & 3 & & & 1 & & & & \\
\hline \multirow{3}{*}{ Close companies } & Not & 1 & 1 & & & & & & & \\
\hline & Partly & 5 & 5 & & & & & & & \\
\hline & $100 \%$ & 5 & & 5 & & & & & & \\
\hline Inventors alone & \multirow[b]{2}{*}{$100 \%$} & 24 & & 15 & 1 & & & & 4 & 4 \\
\hline - " -, at university & & 6 & & 3 & & & & 3 & & \\
\hline Total & & 77 & 39 & 23 & 2 & 1 & 1 & 3 & 4 & 4 \\
\hline \multicolumn{11}{|l|}{ Inventor ownership } \\
\hline Owner & & 47 & 11 & 23 & 1 & 1 & & 3 & 4 & 4 \\
\hline Not owner & & 30 & 28 & & 1 & & 1 & & & \\
\hline Total & & 77 & 39 & 23 & 2 & 1 & 1 & 3 & 4 & 4 \\
\hline
\end{tabular}

Note: "Venture" means private venture capital firm. If the inventors are the only employees in a firm (e.g. a close company), then the inventors belong to the group

"Inventors alone". One of the large firms is a state-owned firm. In one of the medium-sized firms, invention was created at a university, but the research was sponsored, and the patent was owned, by the private firm. One of the small firms is located close to a university. 
Table 4. Number of inventors and female inventors for the patents, number and percent.

\begin{tabular}{|c|c|c|c|c|c|c|c|c|}
\hline \multirow{2}{*}{$\begin{array}{l}\text { Type of firm } \\
\text { where inventors } \\
\text { were active }\end{array}$} & \multicolumn{4}{|c|}{ Number of inventors for the patent } & \multirow{2}{*}{$\begin{array}{l}\text { Total } \\
\text { No. of } \\
\text { patents }\end{array}$} & \multirow{2}{*}{$\begin{array}{c}\text { Total } \\
\text { No. of } \\
\text { inventors }\end{array}$} & \multirow{2}{*}{$\begin{array}{c}\text { Of which } \\
\text { women }\end{array}$} & \multirow{2}{*}{$\begin{array}{l}\text { Percent } \\
\text { women }\end{array}$} \\
\hline & 1 & 2 & 3 & 4 & & & & \\
\hline Large firms & 9 & 8 & 2 & 1 & 20 & 35 & 3 & 9 \\
\hline Medium firms & 4 & 2 & & 2 & 8 & 16 & 0 & 0 \\
\hline Small firms & 5 & & 1 & 2 & 8 & 16 & 2 & 12 \\
\hline Close companies & 8 & 1 & & 2 & 11 & 18 & 0 & 0 \\
\hline Inventors alone & 21 & 8 & & 1 & 30 & 41 & 7 & 17 \\
\hline Total sample & 47 & 19 & 3 & 8 & 77 & 126 & 12 & 10 \\
\hline
\end{tabular}

Note: The total number of inventors in each group is calculated as follows, with example for the group "Close companies": $(8 \times 1)+(1 \times 2)+(2 \times 4)=18$ inventors.

Table 5. Commercialized patents across firm type and inventor ownership, number of patents and percent.

\begin{tabular}{|c|c|c|c|c|c|}
\hline \multirow{3}{*}{$\begin{array}{l}\text { Type of firm } \\
\text { where inventors } \\
\text { were active }\end{array}$} & \multirow{3}{*}{$\begin{array}{l}\text { Inventor } \\
\text { ownership }\end{array}$} & \multicolumn{3}{|c|}{ Number of patents } & \multirow{3}{*}{$\begin{array}{c}\text { Commerciali- } \\
\text { zation rate }\end{array}$} \\
\hline & & \multicolumn{2}{|c|}{ Commercialization } & \multirow[t]{2}{*}{ Total } & \\
\hline & & Yes & No & & \\
\hline Large firms & Not owner & 5 & 15 & 20 & $25 \%$ \\
\hline Medium firms & Not owner & 2 & 6 & 8 & $25 \%$ \\
\hline \multirow{3}{*}{ Small firms } & Not owner & 0 & 1 & 1 & \multirow{3}{*}{$50 \%$} \\
\hline & Partly owner & 2 & 1 & 3 & \\
\hline & Complete owner & 2 & 2 & 4 & \\
\hline \multirow{3}{*}{ Close companies } & Not owner & 1 & 0 & 1 & \multirow{3}{*}{$91 \%$} \\
\hline & Partly owner & 4 & 1 & 5 & \\
\hline & Complete owner & 5 & 0 & 5 & \\
\hline Inventors alone & \multirow[b]{2}{*}{ Complete owner } & 11 & 13 & 24 & \multirow[b]{2}{*}{$43 \%$} \\
\hline -" - at university & & 2 & 4 & 6 & \\
\hline Total & & 34 & 43 & 77 & $44 \%$ \\
\hline Inventor ownership & & Yes & No & Total & Rate \\
\hline Owner & & 26 & 21 & 47 & $55 \%$ \\
\hline Not owner & & 8 & 22 & 30 & $27 \%$ \\
\hline Total & & 34 & 43 & 77 & $44 \%$ \\
\hline
\end{tabular}

Note: One of the large firms is a state-owned firm. In one of the medium firms, invention was created at a university, but the research was sponsored, and the patent was owned, by the private firm. One of the small firms is located in connection with a university. 
Table 6. Commercialized patents across sector, number of patents and percent.

\begin{tabular}{|c|c|c|c|c|}
\hline \multirow{3}{*}{$\begin{array}{l}\text { Type of firm } \\
\text { where inventors } \\
\text { were active }\end{array}$} & \multicolumn{3}{|c|}{ Number of patents } & \multirow{3}{*}{ Commercialization rate } \\
\hline & \multicolumn{2}{|c|}{ Commercialization } & \multirow[t]{2}{*}{ Total } & \\
\hline & Yes & No & & \\
\hline Hygiene articles & 5 & 12 & 17 & $29 \%$ \\
\hline Drugs and substances & 5 & 2 & 7 & $71 \%$ \\
\hline Medical apparatus and equipment & 2 & 5 & 7 & $29 \%$ \\
\hline Medical facilities & 11 & 9 & 20 & $55 \%$ \\
\hline Dentist tools, equipment and material & 7 & 5 & 12 & $58 \%$ \\
\hline Equipment for disabled persons & 2 & 5 & 7 & $29 \%$ \\
\hline Other & 2 & 5 & 7 & $29 \%$ \\
\hline All sample & 34 & 43 & 77 & $44 \%$ \\
\hline
\end{tabular}

Table 8. Year when commercialization started for patents granted in 1994, across firm type, years.

\begin{tabular}{lccc}
\hline \hline Type of firm where inventors were active & Average year & First year & Last year \\
\hline \hline Large firms & 1995 & 1992 & 2000 \\
\cline { 2 - 4 } Medium firms & 1991 & 1991 & 1991 \\
\cline { 2 - 4 } Small firms & 1993 & 1991 & 1995 \\
\cline { 2 - 4 } Close companies & 1992 & 1980 & 1994 \\
\cline { 2 - 4 } Inventors alone & 1994 & 1990 & $\mathbf{1 9 8 9}$ \\
\hline \hline Total & $\mathbf{1 9 9 3}$ & $\mathbf{1 9 0 0}$ \\
\hline
\end{tabular}


Table 7. Reasons why the patent has not been commercialized, number.

\begin{tabular}{|c|c|c|c|c|c|c|}
\hline Reasons why the patent had not been commercialized & $\begin{array}{c}\text { Large firms } \\
\qquad(\mathrm{n}=15)\end{array}$ & $\begin{array}{l}\text { Medium firms } \\
\qquad(\mathrm{n}=6)\end{array}$ & $\begin{array}{c}\text { Small firms } \\
(\mathrm{n}=4)\end{array}$ & $\begin{array}{c}\text { Close } \\
\text { companies } \\
(\mathrm{n}=1)\end{array}$ & $\begin{array}{c}\text { Inventors } \\
\text { alone } \\
(\mathrm{n}=17)\end{array}$ & $\begin{array}{l}\text { All groups } \\
\qquad(\mathrm{n}=43)\end{array}$ \\
\hline Lack of financing for the commercialization & & & & & 7 & 7 \\
\hline Inventors could not find firm willing to manufacture the product & & & 1 & & 7 & 8 \\
\hline The inventor or applying firm had better products & 3 & 4 & & & 1 & 8 \\
\hline Competitors had better products & & & 2 & & 3 & 5 \\
\hline Product is not ready for commercialization yet & 1 & & 1 & 1 & 2 & 5 \\
\hline "Shadow" patent & 4 & & & & 1 & 5 \\
\hline Market was too small or demand was uncertain for the product & 3 & 1 & 1 & & 1 & 6 \\
\hline External advice was necessary for commercialization & & & & & 1 & 1 \\
\hline Product was not good enough & 1 & 1 & & & & 2 \\
\hline The invention was only a part in a larger product & 1 & & & & & 1 \\
\hline Users had difficulties to accept the product & & & & & 1 & 1 \\
\hline Total (number of reasons) & 13 & 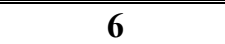 & 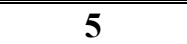 & 1 & 24 & 49 \\
\hline
\end{tabular}

Note: For each patent, the inventor could mention one or two different reason why the patent has not been commercialized yet. This explains why the number of reasons is large than the number of patents. For three patents, the inventors refused to mention the reason. All these three observations can be found in the group "Large firms". 
Table 9. Mode of commercialization of patents, across firm type and inventor ownership, number of patents.

\begin{tabular}{|c|c|c|c|c|c|c|c|c|}
\hline \multirow{3}{*}{$\begin{array}{l}\text { Type of firm } \\
\text { where inventors } \\
\text { are active }\end{array}$} & \multicolumn{2}{|c|}{ Patent sold to } & \multicolumn{2}{|c|}{ Patent licensed to } & \multicolumn{3}{|c|}{ Commercialization in } & \multirow{3}{*}{ Total } \\
\hline & \multirow[b]{2}{*}{$\begin{array}{l}\text { Swedish } \\
\text { Firm }\end{array}$} & \multirow[b]{2}{*}{$\begin{array}{l}\text { Foreign } \\
\text { firm }\end{array}$} & \multirow[b]{2}{*}{$\begin{array}{l}\text { Swedish } \\
\text { firm }\end{array}$} & \multirow[b]{2}{*}{$\begin{array}{l}\text { Foreign } \\
\text { firm }\end{array}$} & \multicolumn{2}{|c|}{ Applying or existing firm } & \multirow[b]{2}{*}{$\begin{array}{l}\text { New } \\
\text { firm }\end{array}$} & \\
\hline & & & & & $\begin{array}{c}\text { Inventor } \\
\text { owner }\end{array}$ & $\begin{array}{l}\text { Inventor } \\
\text { employed }\end{array}$ & & \\
\hline Large firms & & 1 & 1 & & & 3 & & 5 \\
\hline Medium firms & & & & & & 2 & & 2 \\
\hline Small firms & & 1 & & & 3 & & & 4 \\
\hline $\begin{array}{l}\text { Close } \\
\text { companies }\end{array}$ & & & & & 8 & 1 & 1 & 10 \\
\hline Inventors alone & 2 & & 2 & & $5 *$ & & 2 & 11 \\
\hline -“- at university & & & & 1 & & & 1 & 2 \\
\hline Total & 2 & 2 & 3 & 1 & 16 & 6 & 4 & 34 \\
\hline \multicolumn{9}{|l|}{$\begin{array}{l}\text { Inventor } \\
\text { ownership }\end{array}$} \\
\hline Owner & 2 & 1 & 2 & 1 & $16^{*}$ & & 4 & 26 \\
\hline Not owner & & 1 & 1 & & & 6 & & 8 \\
\hline Total & 2 & 2 & 3 & 1 & 16 & 6 & 4 & 34 \\
\hline
\end{tabular}

Table 10. Financing of the commercialization, number of patents.

\begin{tabular}{|c|c|c|c|c|c|c|c|c|}
\hline \multirow{2}{*}{$\begin{array}{l}\text { Type of firm } \\
\text { where } \\
\text { inventors are } \\
\text { active }\end{array}$} & \multicolumn{2}{|c|}{$\begin{array}{c}\text { Inventors are not } \\
\text { owners }\end{array}$} & \multicolumn{5}{|c|}{ Inventors are owners } & \multirow{2}{*}{ Total } \\
\hline & $\begin{array}{l}\text { Financing } \\
\text { in applying } \\
\text { firm }\end{array}$ & \multicolumn{2}{|c|}{$\begin{array}{l}\text { Patent sold } \\
\text { or licensed }\end{array}$} & $\begin{array}{c}\text { Financing in } \\
\text { own existing } \\
\text { firm } \\
\end{array}$ & $\begin{array}{c}\text { Inventors } \\
\text { used own } \\
\text { capital } \\
\end{array}$ & $\begin{array}{c}\text { Inventors } \\
\text { borrowed } \\
\text { capital } \\
\end{array}$ & $\begin{array}{c}\text { Stock } \\
\text { market }\end{array}$ & \\
\hline \multirow{5}{*}{$\begin{array}{l}\text { Large firms } \\
\text { Medium firms } \\
\text { Small firms } \\
\text { Close } \\
\text { companies } \\
\text { Inventors alone }\end{array}$} & 3 & 2 & & & & & & 5 \\
\hline & 2 & & & & & & & 2 \\
\hline & & & 1 & 3 & & & & 4 \\
\hline & 1 & & & $4^{a}$ & 3 & $2^{b}$ & & 10 \\
\hline & & & 5 & 1 & $4^{c}$ & 2 & 1 & 13 \\
\hline Total sample & 6 & 2 & 6 & 8 & 7 & 4 & 1 & 34 \\
\hline
\end{tabular}

Note: According to Table 9, a new firm was started when four patents were commercialized. Of these, one was financed through emission at the stock market; inventors borrowed capital for two patents, and for the last patent, inventors used their own capital.

${ }^{a}$ For one patent in this group, a government capital venture firm financed $20 \%$ of the capital.

${ }^{\mathrm{b}}$ For one of the patents in this group, $30 \%$ of the financing was the inventors' own capital.

${ }^{\mathrm{c}}$ For one patent in this group, a private capital venture firm financed $50 \%$ of the capital. 
Table 11. The role of the inventors during the commercialization, number of patents.

\begin{tabular}{|c|c|c|c|c|c|}
\hline \multirow{3}{*}{$\begin{array}{l}\text { Type of firm } \\
\text { where inventors } \\
\text { were active }\end{array}$} & \multirow{3}{*}{$\begin{array}{l}\text { Inventors' ownership } \\
\text { when patent was granted }\end{array}$} & \multicolumn{4}{|c|}{ Inventors' role during commercialization } \\
\hline & & \multicolumn{2}{|c|}{ Active } & \multicolumn{2}{|c|}{ Passive } \\
\hline & & Owner & Not owner & Owner & Not owner \\
\hline Large firms & Not owner & & 5 & & \\
\hline Medium firms & Not owner & & 2 & & \\
\hline \multirow{2}{*}{ Small firms } & Partly owner & 1 & 1 & & \\
\hline & Complete owner & 2 & & & \\
\hline \multirow{3}{*}{ Close companies } & Not owner & & 1 & & \\
\hline & Partly owner & 4 & & & \\
\hline & Complete owner & 5 & & & \\
\hline Inventors alone & \multirow{2}{*}{ Complete owner } & 7 & 1 & 1 & 1 \\
\hline -“- at university & & 2 & & & \\
\hline Total sample & & 22 & 10 & 1 & 1 \\
\hline \multicolumn{6}{|c|}{ Inventors' ownership when patent was granted } \\
\hline Owner & & 22 & 2 & 1 & 1 \\
\hline Not owner & & & 8 & & \\
\hline Total sample & & 22 & 10 & 1 & 1 \\
\hline
\end{tabular}

Table 12. Juridical type of firm where commercialization took place, for the groups Close companies and Inventors alone, number of patents.

\begin{tabular}{|c|c|c|c|}
\hline \multirow{2}{*}{$\begin{array}{l}\text { Juridical type of firm where } \\
\text { commercialization took place }\end{array}$} & \multicolumn{2}{|c|}{ Firm size } & \multirow{2}{*}{ Of which new firms } \\
\hline & Close company & Inventors alone & \\
\hline Limited company & 9 & 5 & 2 \\
\hline Trading company & & 3 & 2 \\
\hline Private firm * & & 2 & \\
\hline Limited partnership company & & 1 & \\
\hline Total & 9 & 11 & 4 \\
\hline
\end{tabular}

Note: Trading company = "Handelsbolag", Private firm = "Enskild firma", Limited partnership company $=$ "Kommanditbolag". 
Table 13. Performance of commercialization, number of patents.

\begin{tabular}{|c|c|c|c|c|c|c|}
\hline \multirow{2}{*}{$\begin{array}{l}\text { Type of firm where } \\
\text { inventors were active }\end{array}$} & \multicolumn{4}{|c|}{ Performance } & \multirow{2}{*}{$\begin{array}{l}\text { All commer- } \\
\text { cialized patents }\end{array}$} & \multirow{2}{*}{$\begin{array}{c}\text { Total } \\
\text { sample }\end{array}$} \\
\hline & Very good & Good & $\mathrm{OK}$ & $\mathrm{Bad}$ & & \\
\hline Large firms & 3 & & 1 & 1 & 5 & 20 \\
\hline Medium firms & 1 & 1 & & & 2 & 8 \\
\hline Small firms & 1 & 2 & & 1 & 4 & 8 \\
\hline Close companies & 2 & 2 & 4 & 2 & 10 & 11 \\
\hline Inventors alone & 3 & 3 & & 7 & 13 & 30 \\
\hline Total & 10 & 8 & 5 & 12 & 34 & 77 \\
\hline $\begin{array}{l}\text { Note: "Very good" m } \\
\text { profits for the owners, } \\
\text { had some success wit } \\
\text { With "Bad" is meant } \\
\text { incomes at all. }\end{array}$ & $\begin{array}{l}\text { that the pa } \\
\text { or the pate } \\
\text { patent. "O } \\
\text { e owners } 1\end{array}$ & $\begin{array}{l}\text { has b } \\
\text { as leac } \\
\text { s not } \\
\text { made }\end{array}$ & $\begin{array}{l}\text { pe } \\
\text { for }\end{array}$ & $\begin{array}{l}\text { nce, } \\
\text { tent, }\end{array}$ & $\begin{array}{l}\text { ample, a lot of } \\
\text { means that the } \\
\text { either a loss for } \\
\text { times they have }\end{array}$ & $\begin{array}{l}\text { omes or } \\
\text { ers have } \\
\text { owners. } \\
\text { had any }\end{array}$ \\
\hline
\end{tabular}

Table 14. Employment for the inventors and working years generated by the patent, number of patents.

\begin{tabular}{|c|c|c|c|c|c|c|c|c|}
\hline \multirow[t]{2}{*}{$\begin{array}{l}\text { Type of firm } \\
\text { where inventors } \\
\text { were active }\end{array}$} & \multicolumn{2}{|c|}{$\begin{array}{l}\text { Patent gave inventors } \\
\text { employment during } \\
\text { commercialization }\end{array}$} & \multicolumn{6}{|c|}{$\begin{array}{l}\text { Number of working years generated } \\
\text { in Sweden by the patent }\end{array}$} \\
\hline & Yes & No & $>20$ & $16-20$ & $11-15$ & $6-10$ & $1-5$ & $<1$ \\
\hline \multirow{5}{*}{$\begin{array}{l}\text { Large firms } \\
\text { Medium firms } \\
\text { Small firms } \\
\text { Close companies } \\
\text { Inventors alone }\end{array}$} & 5 & & 3 & & & & 1 & 1 \\
\hline & 2 & & 1 & 1 & & & & \\
\hline & 3 & 1 & 1 & & & 2 & 1 & \\
\hline & 10 & & 1 & 1 & 1 & 1 & 6 & \\
\hline & 3 & 10 & 2 & 1 & 1 & & 3 & 6 \\
\hline Total sample & 23 & 11 & 8 & 3 & 2 & 3 & 11 & 7 \\
\hline
\end{tabular}




\section{Table 15. Difficulties when commercializing the patent, number.}

\begin{tabular}{|c|c|c|c|c|c|c|}
\hline Difficulties when the patent was commercialized & $\begin{array}{c}\text { Large firms } \\
\quad(n=5)\end{array}$ & $\begin{array}{l}\text { Medium firms } \\
(\mathrm{n}=2)\end{array}$ & $\begin{array}{l}\text { Small firms } \\
(n=4)\end{array}$ & $\begin{array}{c}\text { Close } \\
\text { companies } \\
(\mathrm{n}=10)\end{array}$ & $\begin{array}{c}\text { Inventors } \\
\text { alone } \\
(\mathrm{n}=13)\end{array}$ & $\begin{array}{c}\text { All groups } \\
(n=34)\end{array}$ \\
\hline Financing of the commercialization & & & 1 & 3 & 4 & 8 \\
\hline Difficult to find firm willing to manufacture the product & & & & & 1 & 1 \\
\hline High fees for patents and to patent bureaus & & & & 3 & & 3 \\
\hline Product was not good enough & 1 & 1 & & & 3 & 5 \\
\hline Scarce with time & & & & & 1 & 1 \\
\hline Users were reluctant to accept the product & & & 1 & & 2 & 3 \\
\hline Difficult to find the right employees & & & & 2 & & 2 \\
\hline The inventor or applying firm had better products & & & 1 & & & 1 \\
\hline Cartel among existing firms in the market & & & & & 1 & 1 \\
\hline Inventor cheated by the producer & & & & & 1 & 1 \\
\hline Inventor had disease & & & & & 1 & 1 \\
\hline No difficulties & 4 & 1 & 1 & 2 & 2 & 10 \\
\hline Total (number of reasons) & $\overline{5}$ & 2 & 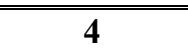 & $\overline{10}$ & 16 & 37 \\
\hline
\end{tabular}

Note: For each patent, the inventor could mention one or two different problems for the commercialization. This explains why the number of problems is large than the number of patents. 
Figure 1. Year when inventors started commercialization of patent (gramted in 1994), numbers.

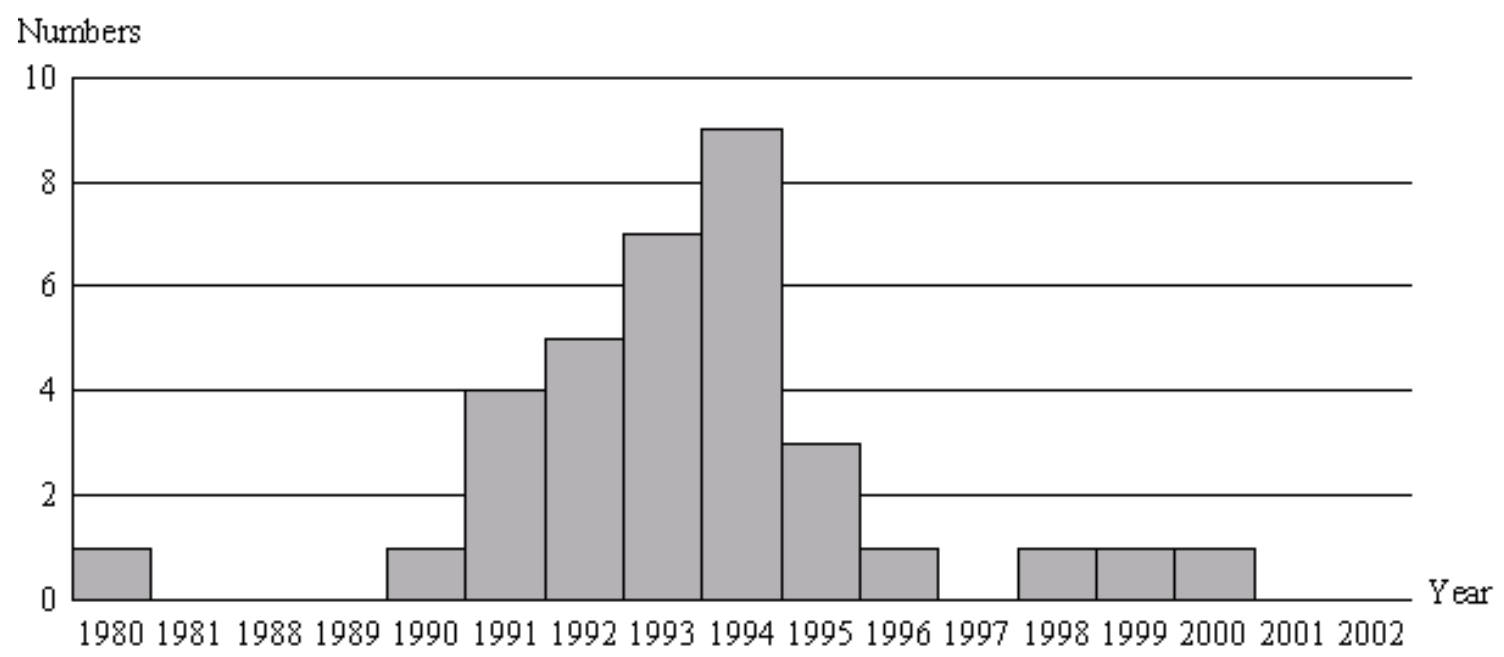




\section{Appendix}

\section{Commercialization of Swedish Patents Confidential}

\begin{tabular}{|c|c|c|c|}
\hline \multicolumn{2}{|c|}{ 1. Basic information about the patent. } & \multicolumn{2}{|l|}{ Identity No. (PRV) } \\
\hline \multirow{3}{*}{$\begin{array}{l}\text { Name of the patent } \\
\text { Sector } \\
\text { Year of application }\end{array}$} & \multirow{3}{*}{ Medicine \& hygiene } & & \\
\hline & & \multirow{2}{*}{$\begin{array}{l}\text { Sub sector } \\
\text { Year when the patent was granted }\end{array}$} & \\
\hline & & & 1994 \\
\hline \multicolumn{4}{|l|}{$\begin{array}{l}\text { Inventor(s) } \\
\text { Applving firm }\end{array}$} \\
\hline \multicolumn{3}{|c|}{ The inventors' share of ownership in the firm when the patent was granted. } & $\%$ \\
\hline \multicolumn{4}{|c|}{ The inventors' and the applying firm's ownership of the patent, when it was granted. } \\
\hline Percent & Inventors & \begin{tabular}{c|l}
$\%$ & Applying firm \\
\end{tabular} & $\%$ \\
\hline
\end{tabular}

2. Type of work place where the invention was created. Mark with one cross.

University (name).

Private firm (in connection with university.

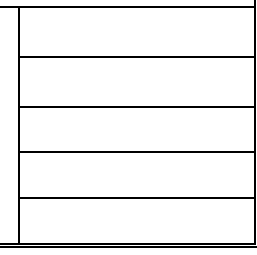

Private firm (not in connection with university)

Government firm or authority

Other work place (mention which)

3. Financing of the invention until the application was filed. Percent.

\begin{tabular}{|l|r|l|}
\hline Government research foundation & $\%$ & University
\end{tabular}

Private research foundation

Applying firm

Other private firm

$\%$ Inventors' own capital

$\%$ Private venture capital

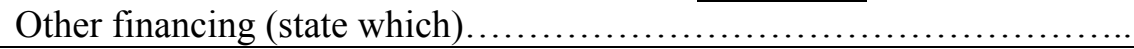

\begin{tabular}{|l|}
\hline$\%$ \\
\hline$\%$ \\
\hline$\%$ \\
\hline$\%$ \\
\hline
\end{tabular}

4. Has the commercialization of the patent started? Mark with one cross.

Definition. With the term "Commercialization" is here meant that measures have

been taken in order to generate incomes from the patent (see question $5 b$ ).

If "Yes" in question 4 then questions 5-9 should be answered, if "No" go to question 10.

5a. Which year started the commercialization?

Note! The commercialization may have started before the patent was granted.

5b. Which mode of commercialization was used? Mark with one cross and state the name of the buyer if the patent was sold.

The patent was sold to another existing Swedish firm

The patent was sold to another existing foreign firm

The patent was commercialized in a new firm (started up for this patent) where the inventors are owners

The patent was commercialized in existing firm where the inventors are owners

The patent was commercialized in existing firm where the inventors are employed

The patent was licensed to another Swedish firm

The patent was licensed to another foreign firm

The inventors sold consulting services based on the patent

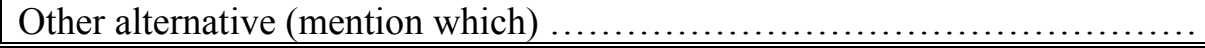

\begin{tabular}{|c|c|c|c|}
\hline $\begin{array}{l}\text { 5c. Has the situation in question } 5 \mathrm{~b} \text { changed since the start? If Yes, } \\
\text { mark with one cross and state year and buyer if any. }\end{array}$ & Buyer (if any) & $\mathrm{X}$ & Year \\
\hline The new / existing firm was sold to a Swedish firm & & & \\
\hline $\begin{array}{l}\text { The new / existing firm was sold to a foreign firm } \\
\text { Other alternative (mention which).................. }\end{array}$ & & & \\
\hline
\end{tabular}




\begin{tabular}{|c|c|}
\hline $\begin{array}{l}\text { 6. If the commercialization was started in a new or existing firm where the invento } \\
\text { how was the commercialization financed? Percent. }\end{array}$ & \\
\hline Inventors' own capital & $\%$ \\
\hline Private venture capital (state source) & $\%$ \\
\hline Government venture capital (state source) . & $\%$ \\
\hline Existing firm's capital & $\%$ \\
\hline Inventors borrowed capital & $\%$ \\
\hline Other financing (state which) & $\%$ \\
\hline
\end{tabular}

7a. The role of the inventors during the commercialization. Mark with one cross.

Active role and owner

Owner but not active role

Active role but not owner

Neither active role nor owner

7b. If the inventors were owners when commercialization started, state juridical firm and ownership.

\begin{tabular}{|l|l|l|l|l|l|l|r|}
\hline Limited & & Trading company & & Other type of firm ............ & & Ownership & $\%$ \\
\hline
\end{tabular}

7c. Has the type of firm, the inventors' ownership or role changed? State when and how.

8. State the incomes / profits, which the patent up to now has generated for the inventors and / or for the firm, which is owned by the inventors.

Incomes when the patent or firm was sold

Incomes in existing or new firm

Profits in existing or new firm

Royalties

Incomes from consulting services

Other incomes (mention which)

9. How many employment years has the patent generated in Sweden since the commercialization started? (If 5 persons were employed in 4 years, then 20 years.)

10. In which other countries and regions (also patent offices, e.g., EPO) has the invention been granted a patent?

\begin{tabular}{||l|l|l|l|l|l||}
\hline & & & & & \\
\hline & & & & & \\
\hline
\end{tabular}

\begin{tabular}{|l|l|l|l|}
\hline 11a. Has the invention been manufactured in other countries than Sweden? & Yes & & No
\end{tabular}

11b. If "Yes", mention countries and starting year.

12a. State one or two difficulties during the commercialization.

12b. If the patent was not commercialized: Why not? State one or two reasons. 